Konstanzer Online-Publikations-System (KOPS)

URL: http://www.ub.uni-konstanz.de/kops/volltexte/2008/6924/

URN: http://nbn-resolving.de/urn:nbn:de:bsz:352-opus-69294

\title{
Determination of Phosphorus-Containing Compounds by Spectrophotometry
}

\author{
Alasdair M. Cook, ${ }^{*}$ Christian G. Daughton, and Martin Alexander \\ Laboratory of Soil Microbiology, Department of Agronomy, Cornell University, Ithaca, New York 14853
}

No single method has been applicable for the determination of total phosphorus in the large spectrum of naturally-occurring and synthetic phosphorus-containing compounds, especially for those of extreme stability; e.g., ionic 0,0 -dialkyl phosphates and $O$-alkyl alkylphosphonates; the available phosphorus assay procedures determine only certain classes of phosphorus compounds. Phosphate esters from cells and tissues have been assayed routinely for total phosphorus after acid hydrolysis (e.g., 1). Nonesterified alkylphosphonates have been determined after alkaline persulfate oxidation (2); however, $O$-alkyl alkylphosphonates are not hydrolyzed quantitatively (3), and the detection limit and the sensitivity in these determinations are poor $(30-1600 \mathrm{nmol} /$ assay $)$.

We have found (Cook and Daughton, unpublished data) that dry ashing with $5 \mathrm{M} \mathrm{HNO}_{3}$ (4) results in incomplete and erratic recovery of dihydrogen 2-aminoethylphosphonate as orthophosphate. Subsequently, we found that a published method for wet ashing of aminoalkylphosphonates (5) could be extended and modified to give a simple, safe, general procedure for nongaseous phosphorus compounds in the 1-50 nmol range; this new procedure is described here. The orthophosphate resulting from the ashing was assayed by the highly sensitive method of Bartlett (1).

\section{EXPERIMENTAL}

Apparatus. Wet ashing was done with a fluidized sandbath (Tecam SBL-1, Techne Inc., Princeton, N.J.). (Caution: All ashing must be done in a fume hood equipped with a safety screen.) The bath was fluidized with compressed air ( 3 psig) precleaned of oil and water. Samples were ashed in $20 \times 150 \mathrm{~mm}$ screwcap Pyrex tubes held in a circular 25-place stainless-steel rack. A simple accessory was constructed to allow easy placement and removal of the rack from the bath and to prevent sand overflow and contamination of the samples. An aluminum cake pan (22-cm base, $26.5-\mathrm{cm}$ diameter top, $18 \mathrm{~cm}$ deep) with a $17-\mathrm{cm}$ diameter hole in the base held two horizontal bars through its side, $2 \mathrm{~cm}$ from the base, and the rack was suspended on the bars. This assembly seated firmly on the inside lip of the bath. An aluminum plate $(30-\mathrm{cm}$ diameter) with $20-\mathrm{mm}$ holes was designed to slide over the tops of the tubes and rest on the pan $2 \mathrm{~cm}$ below the tube tops. A dial thermometer (range $0-250^{\circ} \mathrm{C}$ ) was used to measure temperature.
Absorbance values were measured with a Spectronic 88 spectrophotometer (Bausch \& Lomb, Rochester, N.Y.) equipped with a micro flow-through cell of $1-\mathrm{cm}$ path length. Calibrated Gilson automatic pipets were used except where indicated. All glassware was cleaned with nitric acid to eliminate contaminative phosphate (6).

The acid digestion mixture contained $0.75 \mathrm{~mol} \mathrm{HClO}_{4}, 1.0 \mathrm{~mol}$ $\mathrm{H}_{2} \mathrm{SO}_{4}$ and $10.5 \mathrm{~mol} \mathrm{HNO}_{3}$ in $1 \mathrm{~L}$ deionized distilled water as in (5). (Important: $\mathrm{Mix}$ in the following order: $\mathrm{H}_{2} \mathrm{O}, \mathrm{H}_{2} \mathrm{SO}_{4}, \mathrm{HNO}_{3}$, and $\mathrm{HClO}_{4}$.) The ammonium molybdate solution was $10 \mathrm{mM}$ in water. The Fiske-SubbaRow reagent contained $0.79 \mathrm{~mol} \mathrm{NaHSO}_{3}$, $10 \mathrm{mmol}$ 1-amino-2-naphthol-4-sulfonic acid, and $40 \mathrm{mmol} \mathrm{Na} 2 \mathrm{SO}_{3}$ in $1 \mathrm{~L}$ distilled water (1).

Ashing and Assay Procedures. Standards were prepared in either water or buffered salts solution (6). Biological samples (e.g., from bacterial cultures) were filtered through membranes of $0.2-\mu \mathrm{m}$ pore diameter to allow for analysis of the cell-free fluid. Samples $(1.00 \mathrm{~mL})$ were measured into the ashing tubes, and 1.50 $\mathrm{mL}$ of digestion acid was added by Dispensette (Brinkmann Instruments Inc.) to each tube. The fluidized bath was brought to $80^{\circ} \mathrm{C}$, and the samples were placed therein. The temperature was increased at $10^{\circ} \mathrm{C} / \mathrm{min}$ to $225-230^{\circ} \mathrm{C}$ for $1-1.25 \mathrm{~h}$ (the final temperature could be maintained for at least $2.5 \mathrm{~h}$ ) after which the samples were removed. (Note: The air pressure should be decreased during warming of the bath to prevent excessive fluidization.) Loss of phosphorus compounds suspected to be volatile (e.g., $8 \%$ with dimethyl methylphosphonate) was eliminated by preincubation $(30 \mathrm{~min}$ ) with the acid-digestion mixture in capped tubes at $80^{\circ} \mathrm{C}$; the caps were then removed, and the standard ashing procedure was followed.

At the end of the ashing, the $\mathrm{H}_{2} \mathrm{SO}_{4}(1.5 \mathrm{mmol}, 100 \mu \mathrm{L})$ remained in each tube. When the tubes reached ambient temperature, $0.86 \mathrm{~mL}$ of ammonium molybdate and $40 \mu \mathrm{L}$ of Fiske-SubbaRow reagent were added. The tubes were sealed with Teflon-lined caps, heated at $100{ }^{\circ} \mathrm{C}$ for $10 \mathrm{~min}$, cooled, and mixed, and the absorbance at $830 \mathrm{~nm}$ was read against water.

Chemicals. Dimethyl hydrogen phosphate (DMP) was obtained from Pfaltz \& Bauer (Stamford, Conn.). Diethyl hydrogen phosphate (DEP) was purchased from Eastman Organic Chemical Div. (Rachester, N.Y.). Dimethyl methylphosphonate (DMMPn) was purchased from Aldrich Chemical Co. (Metuchen, N.J.). The potassium salts of 0,0 -dimethyl and $O, 0$-diethyl phosphorothioate and $O, O$-dimethyl and $O, O$-diethyl phosphorodithioate (DMTP, DETP, DMDTP, and DEDTP, respectively) were generous gifts of American Cyanamid Co. (Princeton, N.J.). The potassium salt 
Table I. Analysis of Phosphorus-Containing Compounds as Inorganic Orthophosphate ${ }^{a}$

$\begin{array}{lccc}\text { compound } & \begin{array}{c}\text { regression } \\ \text { coefficient }\end{array} & \text { intercept } & \begin{array}{c}\text { correlation } \\ \text { coefficient }\end{array} \\ \mathrm{Pi}^{b} & 0.0254 & 0.015 & 0.999 \\ \mathrm{Pi}^{c} & 0.0250 & 0.010 & 0.999 \\ \mathrm{Pi}^{d} & 0.0254 & 0.027 & 0.999 \\ \text { phosphite } & 0.0249 & 0.041 & 0.999 \\ \text { DEP } & 0.0260 & 0.061 & 0.998 \\ \text { DEDTP } & 0.0257 & 0.029 & 0.999 \\ \text { IMPn } & 0.0247 & 0.032 & 0.999 \\ \text { DMMPn } & 0.0256 & 0.078 & 0.999 \\ \text { MPhPn } & 0.0253 & 0.087 & 0.997 \\ \text { Orthene } & 0.0256 & 0.075 & 0.999\end{array}$

${ }^{a}$ Least squares regression equations of $A_{830}$ vs. [P] (nmol/assay) for inorganic or thophosphate, phosphite, and representative organophosphorus compounds. Assays were done in $1-\mathrm{mL}$ final volumes. Regression lines and correlation coefficients were calculated for graphs of 1225 points in the range $0-50 \mathrm{nmol}$ phosphorus/assay. Control experiments were done without ashing at low (1.6 $\mu \mathrm{mol})$ and high $(8.1 \mu \mathrm{mol})$ molybdate concentrations. The orthophosphate in samples subjected to wet ashing was assayed as described in the Methods section at the high molybdate concentration. B Bartlett assay, low molybdenum concentration. ${ }^{c}$ Bartlett assay, high molybdenum concentration. d Assay of samples subjected to wet ashing.

of $O$-methyl phenylphosphonothioate (MPhPnT), O-methyl hydrogen phenylphosphonate (MPhPn), and dihydrogen phenylphosphonate ( $\mathrm{PhPn}$ ) were gifts of Velsicol Chemical Corp. (Chicago, Ill.). Dihydrogen methylphosphonate (MPn), O-isopropyl hydrogen methylphosphonate (IMPn), and $O$-pinacolyl hydrogen methylphosphonate (PMPn) were obtained from Chemical Systems Laboratory (Aberdeen Proving Ground, Md.). $O, S$-Dimethyl acetylphosphoramidothioate (Orthene) was a gift of Chevron Chemical Co. (Richmond, Calif.).

\section{RESULTS AND DISCUSSION}

A major problem with the ashing procedure as described by Kirkpatrick and Bishop (5) was explosive bumping of the samples. This difficulty was partially alleviated by the use of $18-\mathrm{mm}$ i.d. culture tubes. However, we have eliminated this problem by using a fluidized bath and temperature programing from $80^{\circ} \mathrm{C}$. Irreproducible volume changes in the poorly closed tubes that were previously used during development of color at $100^{\circ} \mathrm{C}$ (1) were eliminated by using screw-cap tubes. Use of these tubes also facilitated the preincubation step that permitted quantitative assay of volatile compounds.

Our total phosphorus ultramicro assay had a regression coefficient for $A$ vs. nmol P of 0.025 (SEM for 12 assays of MPn was $2.2 \%$ ), which agrees with Bartlett's assay (1). Two assays were described by Bartlett (1). The first, which was outlined in detail, was for low concentrations of molybdate and $\mathrm{H}_{2} \mathrm{SO}_{4}(1.6 \mu \mathrm{mol}$ and $0.3-0.9 \mathrm{mmol}$, respectively, per $1-\mathrm{mL}$ assay). The second method was for a high concentration of molybdate in the assay $(8.1 \mu \mathrm{mol} / \mathrm{mL})$, and we found the usable range of $\mathrm{H}_{2} \mathrm{SO}_{4}$ concentration to be $1.1-1.8 \mathrm{mmol} / \mathrm{mL}$. Both assays gave identical standard graphs (see equations in Table I). A high concentration of molybdate in the assay enabled the use of a larger amount of $\mathrm{H}_{2} \mathrm{SO}_{4}$ in the wet ashing procedure, a precaution that assures safe ashings with perchloric acid (4). The sensitivity of our assay is at least $25 \%$ greater than that reported by Kirkpatrick and Bishop (5), who used a modified reducing agent in the phosphate assay.

The least squares regression lines of standard graphs ( $A$ vs. P, nmol/1-mL assay) for several phosphorus-containing compounds are shown in Table I. The correlation coefficients are high, and the reproducibility of the regression coefficients $(\mathrm{SEM}=1.6 \%)$ indicates quantitative conversion of the organic phosphorus to inorganic orthophosphate. The absorbance of the reagent blank corresponded to about 1-3 nmol phosphorus per assay (depending on the batch of digestion acid) and was unaffected by the presence of EDTA (cf. 1), fluctuations in residual sulfuric acid, or delay between addition of reagents and of color development. The regression coefficients for absorbance vs. [P] for DMP, DMTP, DETP, DMDTP, PMPn, $\mathrm{MPhPnT}$, and $\mathrm{PhPn}$ were within $10 \%$ of the values in Table I.

We routinely use this assay for the study of bacterial metabolism of phosphorus-containing breakdown products of organophosphorus pesticides and in investigations of the sorption of organophosphorus compounds by soil. A complement to our assay for total phosphorus is a reliable assay that is specific for inorganic orthophosphate in complex mixtures of acid-labile organophosphates and phosphite (7). This assay was done in a $5-\mathrm{mL}$ final volume and, contrary to the procedure as published (7), reproducibility was obtained only when the arsenite/citrate reagent was added at least 30 $\mathrm{s}$ after addition of the molybdate reagent. Hepes buffer, when present at concentrations greater than $15 \mu \mathrm{mol}$ per assay, interfered with both the Dick and Tabatabai (7) and Bartlett (1) (non-ashed samples) assays by precipitation of the heteropoly blue complex. Tris buffer at $80 \mu \mathrm{mol} /$ assay did not interfere.

\section{LITERATURE CITED}

(1) G. R. Bartiett, J. Biol. Chem, 234, 466-468 (1959)

(2) J. Kolmerten and J. Epstein, Anal. Chem., 30, 1536-1537 (1958).

(3) R. May, Anal. Chem., 31, 308-310 (1959).

(4) T. Greweling, Search (Agriculture, Agronomy 6, Ithaca, N.Y.) 6(8), 1-35 (1976).

(5) D. S. Kirkpatrick and S. H. Bishop, Anal. Chem., 43, 1707-1709 (1971)

(6) A. M. Cook, C. G. Daughton, and M. Alexander, J. Bacteriol., 133, 85-90 (1978).

(7) W. A. Dick and M. A. Tabatabai, J. Environ. Qual., 6, 82-85 (1977). 